\title{
A study on important factors influencing customer relationship management: A case study of Mobile service provider
}

\author{
Naser Azad ${ }^{*}$ and Shahram Hashemi
}

Department of Management, Islamic Azad University, South Tehran Branch, Tehran, Iran

\begin{tabular}{l}
\hline C H R O N I C L E \\
\hline Article history: \\
Received December 2, 2012 \\
Received in revised format \\
2 March 2013 \\
Accepted 5 March 2013 \\
Available online \\
March 72013 \\
\hline Keywords: \\
Mobile industry \\
Customer relationship \\
management \\
Factor analysis
\end{tabular}
\section{A B S T R A C T}

\begin{abstract}
Customers are considered as essential assets in any organizations including mobile services. During the past few years, mobile industry is growing rapidly and the competitions among business owners increases steadily. In this paper, we present an empirical investigation to find important factors influencing customer relationship management. The proposed study of this paper designs a questionnaire and distributes it among 253 customers in mobile industry in city of Tehran, Iran. All questions are designed in Likert scale and Cronbach alpha is calculated as 0.816 , which is relatively reliable value. There were 28 questions in this survey and the proposed study extracts five important factors including economic factors, communication skills, organizational resources, service capabilities and flexible market.
\end{abstract}

\section{Introduction}

Customers are considered as essential assets in any organizations including mobile services. During the past few years, mobile industry is growing rapidly and the competitions among business owners increases steadily. Steadily, customers are anticipating more and better service and consequently, business owners require guidelines and frameworks to address people's requirements. The idea of process completeness assists us to investigate service from the customer's viewpoint. Process completeness is normally obtained when a firm's service delivery system fits customer's expectations. While customers normally require alternative services business owners may focus only on single services. Therefore, there is a need to find a compromise solution strategy between these two components (Piccoli et al., 2009).

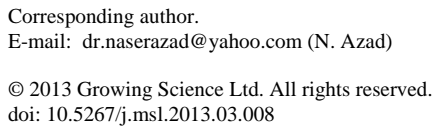


Wouters (2004) investigated whether customer service actually had order winning potential in B2B situations, which customer service strategies were deployed, and what detected customer service relevance. They determined four customer service strategy options including customer integration, customer adaptation, logistical precision, and standard customer service. In their survey, various firms were positioned in the least attractive customer service strategy option: customer adaptation. Partially, this is caused by challenges in evaluating the customer service capability and the customer's sensitivity for customer service.

According to Gil et al. (2008) job satisfaction of service employees plays an essential role in customer evaluation of service result along with other variables such as the service process, perceived service value and customer satisfaction. Williams et al. (2011) compared customer behaviour of stayers and defectors in B2B services based on respondents from a Fortune 100 company. The results indicated that the commonly used customer metrics of service quality, satisfaction, and behavioral intentions had some differences between stayers and defectors and their findings had substantial implications for the design and use of customer-focused research by managers.

Bygballe et al. (2012) investigated the organization and management of international supply from a total cost perspective including purchasing and logistics costs, as well as customer service and agility. They utilized the supply management literature and an instance of a Norwegian retail and wholesale company to analyze and discuss these configurations and their impacts on total costs and customer service. The paper's theoretical contribution is the conceptualization of a total expenditure perspective on international supply management.

Merlo et al. (2006) argued that the structural, relational and cognitive dimensions of social capital within retail stores could provide an insight into the antecedents of customer service orientation and store creativity. Steven et al. (2012) studied the linkages between customer service, customer satisfaction, and firm performance in the US airline industry. More specifically, they examined the moderating impacts of market concentration and firm dominance on the service-satisfactionperformance relationship. They reported that market concentration dampens the relationship between customer satisfaction and airline profitability.

Kang and Hyun (2011) performed an investigation to detect the optimal aspects of communication style for customer-oriented service employees and to test different ways in which the customeroriented service employee (COSE) induces luxury restaurant patrons' dedicational behaviors. The results of data analysis disclosed that five kinds of communication styles including attentive, friendly, impression leaving, open, and relaxed had positive impacts on COSE, while one communication style maintained a negative impact.

According to Butcher et al. (2009), small hospitality business units are normally unwilling to embrace business improvement activities in general and customer service training in particular. Yang and Liu (2009) proposed a standard for managing customer service processes, in which language-action was integrated into blogs to leverage blog characteristics. This standard includes new specified dialogue patterns for collaboration, suggested customer service processes, and supporting system architecture.

In this paper, we present an empirical study to find important factors on better serving customers who are using mobile services. The organization of this paper first presents the proposed study in section 2 , while section 3 describes details of our findings and concluding remarks are given in the last to summarize the contribution of the paper.

\section{The proposed study}

The proposed study of this paper presents an empirical investigation to find important factors influencing customer relationship management. The proposed study of this paper designs a questionnaire and distributes it among 253 customers in mobile industry in city of Tehran, Iran. All 
questions are designed in Likert scale and Cronbach alpha is calculated as 0.65 , which is relatively reliable value. There were 28 questions in this survey and the proposed study extracts five important factors. Table 1 introduces 28 factors detected in our survey as follows,

Table 1

The summary of 28 different variables

\begin{tabular}{|c|c|c|c|c|c|}
\hline No. & Variable & Reference & No. & Variable & Reference \\
\hline 1. & Investment on equipment & Piccoli et al., 2009 & 15. & Clustering customers & Dong et al., 2010 \\
\hline 2. & Customer oriented approach & Kang \& Hyun, 2011 & 16. & Dynamic market & Bygballe et al., 2012 \\
\hline 3. & Competition in related industries & Steven et al., 2012 & 17. & Customer satisfaction & Gil et al., 2008 \\
\hline 4. & Faster customer services & Steven et al., 2012 & 18. & Professional services & Le Bon \& Hughes, 2009 \\
\hline 5. & Providing better quality services & Florez et al., 2012 & 19. & Economic changes & Kankanhalli et al., 2005 \\
\hline 6. & $\begin{array}{l}\text { Increasing communication skills } \\
\text { with customers }\end{array}$ & $\begin{array}{l}\text { Le Bon \& Hughes, } \\
2009\end{array}$ & 20. & Economic recession & Kankanhalli et al., 2005 \\
\hline 7. & $\begin{array}{l}\text { Having competitive advantage on } \\
\text { market }\end{array}$ & Merlo et al., 2006 & 21. & Learners organizations & Piccoli et al., 2009 \\
\hline 8. & Pricing strategy & Bygballe et al., 2012 & 22. & Organization status among competitors & Merlo et al., 2006 \\
\hline 9. & $\begin{array}{l}\text { Long term relationships with } \\
\text { customers }\end{array}$ & Wouters et al., 2004 & 23. & Customer loyalty & Williams et al., 2011 \\
\hline 10. & $\begin{array}{l}\text { Good insider organization } \\
\text { cooperation }\end{array}$ & Yoo et al., 2011 & 24. & Demand elasticity & Florez et al., 2012 \\
\hline 11. & $\begin{array}{l}\text { Knowledge oriented } \quad \text { within } \\
\text { organization }\end{array}$ & Piccoli et al., 2009 & 25. & Building a good brand & Wouters et al., 2004 \\
\hline 12. & Building informal communications & Steven et al., 2012 & 26. & Raw materials & Bygballe et al., 2012 \\
\hline 13. & Detecting customers’ needs & Florez et al., 2012 & 27. & Product innovation & Merlo et al., 2006 \\
\hline 14. & $\begin{array}{l}\text { Organizational equipment for better } \\
\text { serving customers }\end{array}$ & Kang \& Hyun, 2011 & 28. & Service contracts & Yoo et al., 2011 \\
\hline
\end{tabular}

We have performed factor analysis using 28 variables introduced in Table 1 and KMO and Bartlett's Test has been used to verify the overall questionnaire. The result of Kaiser-Meyer-Olkin Measure of Sampling Adequacy is equal to 0.655. In addition, the result of Bartlett's Test of Sphericity yields Chi-Square of 720.005 with sig. $=0.000$. Finally, Cronbach's Alpha based on standardized items is equal to 0.816, which is well above the minimum desirable limit. In addition, Fig. 1 demonstrates the results of Scree Plot, which indicates that we can extract five factors out of our factor analysis.

Scree Plot

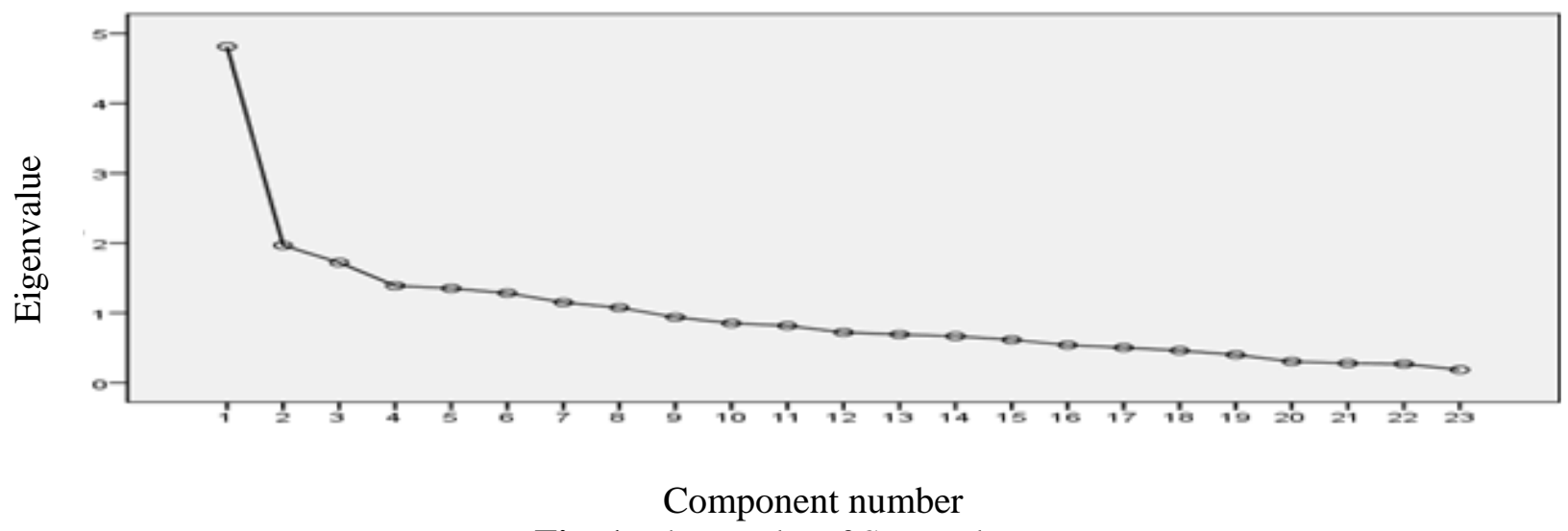

Fig. 1. The results of Scree Plot

According to our survey, we have detected five important items including economic factors, communication skills, organizational resources, service capabilities and flexible market.

\section{The results}

In this section, we present details of our findings on five important factors.

\subsection{The first item: Economical factors}

The first important factor is devoted to economic factors and Table 2 demonstrates the results of our survey as follows, 


\section{Table 2}

The summary of factor associated with economic factor

\begin{tabular}{lcccc}
\hline Option & Factor weight & Eigenvalues & \% of variance & Accumulated \\
\hline Economic recession & .800 & & & \\
Economic changes & .822 & 2.048 & 51.202 & 51.202 \\
Inside organization cooperation & .499 & & \\
Pricing services & .694 & & & \\
\hline Cronbach alph $=0.676$ & & & &
\end{tabular}

The results of Table 2 explain that economic change is number one priority followed by economic recession.

\subsection{The second item: Communication knowledge}

The second option is associated with communication knowledge and Table 3 demonstrates the results of our survey on this factor.

\section{Table 3}

The summary of factor associated with communication knowledge

\begin{tabular}{lcccc}
\hline Option & Factor weight & Eigenvalues & \% of variance & Accumulated \\
\hline Knowledge oriented organization & .761 & 1.516 & 50.519 & 50.519 \\
Building formal and informal channels & .663 & & & \\
Building organizational learning groups & .705 & & & \\
\hline Cronbach alph $=0.5$ & & & & \\
\hline
\end{tabular}

The results of Table 3 show that knowledge oriented organization is number one priority followed by building organizational learning groups and establishing formal and informal channels are the last priority in our survey.

\subsection{The third item: Organizational resources}

The third option in our survey is associated with organizational resources and Table 4 presents details of our findings,

\section{Table 4}

The summary of factor associated with organizational resources

\begin{tabular}{lcccc}
\hline \multicolumn{1}{c}{ Option } & Factor weight & Eigenvalue & \% ofvariance & Accumulated \\
\hline Brank reputation & .538 & & & \\
Access to raw materials & .772 & 1.028 & 17.125 & 53.423 \\
Innovation in new services & .641 & & \\
Having service contracts & .585 & & \\
Better resources to provide better services & .534 & & \\
Investment on equipment & .504 & & & \\
\hline Cronbach alph $=0.643$ & & &
\end{tabular}

According to the results of Table 4, Access to raw materials is number one priority followed by product innovation and better service contracts.

\subsection{The fourth item: Service capabilities}

The fourth item is related to service capabilities and Table 5 demonstrates the results of our survey.

\section{Table 5}

The summary of factor associated with service capabilities

\begin{tabular}{|c|c|c|c|c|}
\hline Option & Factor weight & Eigenvalues & $\%$ of variance & Accumulated \\
\hline Professional services & .686 & & & \\
\hline Customer loyalty & .729 & 1.851 & 46.279 & 46.279 \\
\hline Customer satisfaction & .686 & & & \\
\hline Building a long term relationship with customers & .615 & & & \\
\hline
\end{tabular}


The results indicate that customer loyalty is number one priority followed by professional services and customer satisfaction.

\subsection{The fifth item: Service capabilities}

The fourth item is related to service capabilities and Table 5 demonstrates the results of our survey.

\section{Table 5}

The summary of factor associated with flexible market

\begin{tabular}{lcccc}
\hline \multicolumn{1}{c}{ Option } & Factor weight & Eigenvalues & \% of variance & Accumulated \\
\hline Professional skills on customer communications & .443 & & & \\
Potential market & .679 & & & \\
Clustering market & .845 & 1.033 & 34.420 & 80.126 \\
\hline Cronbach alph $=0.37$ & & &
\end{tabular}

The results of Table 5 show that clustering market is number one priority followed by potential market and building professional skills on customer communications is the last priority.

\section{Conclusion}

In this paper, we have presented an empirical investigation on extracting various factors influencing better serving customers in mobile industry in Iran. The proposed study used factor analysis and detected five important figures including economic factors, communication skills, organizational resources, service capabilities and flexible market. In our survey, in terms of economic factors, economic change is number one priority followed by economic recession. In addition, in terms of communication knowledge, knowledge oriented organization is number one priority followed by building organizational learning groups and establishing formal and informal channels are the last priority in our survey. In terms of organizational resources, "raw materials" is number one priority followed by "product innovation" and "better service contracts". In terms of service capabilities, "customer loyalty" is number one priority followed by "professional services" and "customer satisfaction". Finally, flexible market is the last item where "clustering market" is number one priority followed by "potential market" and "building professional skills on customer communications” is the last priority.

\section{Reference}

Butcher, K., Sparks, B., \& McColl-Kennedy, J. (2009). Predictors of customer service training in hospitality firms. International Journal of Hospitality Management, 28(3), 389-396.

Bygballe, L. E., Bø, E., \& Grønland, S. E. (2012). Managing international supply: The balance between total costs and customer service. Industrial Marketing Management, 41(3), 394-401.

Dong, P., Zhang, H., Luo, H., Chi, T. Y., \& Kuo, S. Y. (2010). A network-based mobility management scheme for future Internet. Computers \& electrical engineering, 36(2), 291-302.

Florez, R., Ramon, J. M., Velez, M., Alvarez-Dardet, M. C., Araujo, P., \& Sanchez, J. M. (2012). The role of management control systems on inter-organisational efficiency: An analysis of export performance. Studies in Managerial and Financial Accounting, 25, 195-222.

Gil, I., Berenguer, G., \& Cervera, A. (2008). The roles of service encounters, service value, and job satisfaction in achieving customer satisfaction in business relationships. Industrial marketing management, 37(8), 921-939.

Kang, J., \& Hyun, S. S. (2011). Effective communication styles for the customer-oriented service employee: Inducing dedicational behaviors in luxury restaurant patrons. International Journal of Hospitality Management, 31(3), 772-785. 
Kankanhalli, A., Tan, B. C., \& Wei, K. K. (2005). Understanding seeking from electronic knowledge repositories: An empirical study. Journal of the American Society for Information Science and Technology, 56(11), 1156-1166.

Le Bon, J., \& Hughes, D. E. (2009). The dilemma of outsourced customer service and care: Research propositions from a transaction cost perspective. Industrial Marketing Management, 38(4), 404410.

Merlo, O., Bell, S. J., Mengüç, B., \& Whitwell, G. J. (2006). Social capital, customer service orientation and creativity in retail stores. Journal of Business Research, 59(12), 1214-1221.

Piccoli, G., Brohman, M. K., Watson, R. T., \& Parasuraman, A. (2009). Process completeness: Strategies for aligning service systems with customers' service needs. Business Horizons, 52(4), 367-376.

Steven, A. B., Dong, Y., \& Dresner, M. (2012). Linkages between customer service, customer satisfaction and performance in the airline industry: Investigation of non-linearities and moderating effects. Transportation Research Part E: Logistics and Transportation Review, 48(4), 743-754.

Williams, P., Khan, M. S., Ashill, N. J., \& Naumann, E. (2011). Customer attitudes of stayers and defectors in B2B services: Are they really different?. Industrial Marketing Management, 40(5), 805-815.

Wouters, J. P. (2004). Customer service strategy options: A multiple case study in a B2B setting. Industrial Marketing Management, 33(7), 583-592.

Yang, H. L., \& Liu, C. L. (2009). A new standard of on-line customer service process: Integrating language-action into blogs. Computer Standards \& Interfaces, 31(1), 227-245.

Yoo, J. J., Arnold, T. J., \& Frankwick, G. L. (2011). Effects of positive customer-to-customer service interaction. Journal of Business Research. 65(9), 1313-1320. 